\title{
Cloning of mouse $\beta$-casein gene sequences
}

(Recombinant DNA; pBR322 cloning vehicle; messenger RNA purification; hybridizations)

\author{
Nozer M. Mehta, M. Raafat El-Gewely *, Jay Joshi, Robert B. Helling * and Mihir R. Banerjee ** \\ Tumor Biology Laboratory, School of Life Sciences, University of Nebraska, 201 Lyman Hall, Lincoln, NE 68588, and \\ - Division of Biological Sciences, University of Michigan, Natural Science Building, Ann Arbor, MI 48109 (U.S.A.)
}

(Received April 20th, 1981)

(Accepted June 30th, 1981)

\section{SUMMARY}

Casein messenger RNAs (mRNAcsn) were purified from lactating mammary glands of BALB/c mice and used as a starting material for cloning of casein gene sequences. Double-stranded casein cDNA (ds-cDNAscn) was prepared and bluntend ligated to HindIII-specific DNA linker molecules. After digestion with HindIII, the dsDNAcsn was inserted into the HindIII site of plasmid pBR322, using T4 DNA ligase. Escherichia coli strain RH202 was transformed with the hybrid plasmids, and transformants were selected for resistance to ampicillin. Electrophoresis of HindIII-digested hybrid plasmid DNAs, followed by Southern transfer and hybridization to [32P]cDNAcsn, revealed that one of the hybrid-plasmid-containing colonies, designated pCas51, contained a 400 . bp insert which hybridized to the [ $\left.{ }^{32} \mathrm{P}\right] \mathrm{cDNAcsn}$. Purification of the individual casein mRNAs (mRNAcsn $\alpha, \beta$ and $\gamma$ ) and solution hybridization of nick-translated insert DNA to each of these revealed that pCas51 contained sequences complementary primarily to mRNAcsn $\beta$.

Caseins constitute the major milk proteins and their synthesis is under hormonal control. The induction of the mRNAs for the three major caseins is the result of the synergistic stimulatory action of a glucocorticoid (hydrocortisone) and a polypeptide (prolactin) hormone (Banerjee, 1976). Accumulation of

\footnotetext{
** Reprint requests should be sent to Mihir R. Banerjee at the first address. On request, the authors will supply a detailed experimental evidence for the conclusions reached in this short presentation.

Abbreviations: bp, base pairs; cDNAcsn, DNA complementary to casein messenger ribonucleic acid; csn, casein; dscDNAcsn, double-stranded cDNAcsn; dTT, dithiothreitol; kb, kïlobase pairs; mRNAcsn, casein messenger ribonucleic acid; SH-agarose, sulfhydryl agarose; ss-cDNAcsn, singlestranded cDNAcsn; TCA, trichloroacetic acid.
}

mRNAcsn as measured by hybridization to cDNAcsn requires the presence of both hormones (Ganguly et al., 1979; 1980; Mehta et al., 1980). We were interested, therefore, in determining the specific regulatory role of each of these two hormones at the transcriptional level of control of the casein gene. Accordingly, studies were undertaken to amplify the casein gene sequences by cloning in a bacterial plasmid, so that cloned DNA sequences could be hybridized to labeled nuclear transcripts synthesized in vitro, in conditions of DNA excess (McKnight and Palmiter, 1979). Since casein mRNAs are relatively abundant in mammary gland alveolar cells, we used purified casein mRNAs from lactating mamrnary glands of BALB/c mice as a starting material for the cloning experiments. 
Total mammary gland RNA was isolated by extraction with phenol-chloroform (Ganguly et al., 1979), mRNAcsn purified and used as the template for synthesis of a single-stranded cDNA, using AVIV reverse transcriptase as previously described (Ganguly et al., 1979). Double-stranded DNA synthesis was performed using 25 units $/ \mathrm{ml} E$. coli DNA polymerase $I$ and $20 \mu \mathrm{g} / \mathrm{ml}$ of ss-cDNAcsn, at $30^{\circ} \mathrm{C}$ for 60 min. Starting with about $25 \mu \mathrm{g}$ of purified $\mathrm{mRNA}$, we obtained $2 \mu g$ of ss-cDNAcsn and $1.5 \mu$ of dscDNAcsn.

After S1 digestion, ds-cDNAcsn was electrophoresed on a $1.5 \%$ agarose gel in Peacock's buffer (Peacock and Dingman, 1967) at $150 \mathrm{~V}$ for $2 \mathrm{~h}$. Molecules of ds-cDNAcsr ranging in size from 600 to 1500 bp were cut out, and eluted. DNA "linker" squences specific for the restriction endonuclease llindIII (C-C-A-A-G-C.T-T-G-G) were phosphoryl: ted and labeled at the 5 'end using $\left[\gamma^{32} \mathrm{P}\right] \mathrm{dATP}$ (10 Ci/mmol), and the ${ }^{32}$ P-labeled linker DNA was ligated to ds-cDNAcsn using T4 DNA ligase (BRL). The bacterial plasmid pBR322 and the ds-cDNAcsn were separately digested with HindIII and then ligated together with T4 DNA ligase in a 50-fold molar excess of plasmid DNA.

E. coli strain RH202 (Adams et al., 1979) was transformed with the recombinant plasmid DNA. The cells were grown at $37^{\circ} \mathrm{C}$ for $90-120 \mathrm{~min}$ with good aeration to allow expression of the transformed genes before selection. Transformants were selected by plating onto $T$-agar supplemented with $40 \mu \mathrm{g} / \mathrm{ml}$ ampicillin. They were then scored for tetracycline sensitivity because the HindIII cloning site lies at the promoter end of the gene for resistar ze (Rodriguez et al., 1979; Widera et al., 1978), ait some transformants with cloned genes might not express resistance. Purified preparations of plasmid DNA were obtained essentially as described (El-Gewely and Helling, 1980) and with yields of 2 to $5 \mathrm{mig}$ of supercoiled DNA per litre cu'ture. Recombinant plasmid DNA preparations, with and without digestion by appropriate restriction endonucleases, were electrophoresed through $1 \%$ agarose gels and the bands transferred to nitrocellulose filters by the procedure of Southern (i975) as modified by Thonias (1980). Of the colonies thus screened, one colony (pCas51) was found to contain an inserted sequence of about 400 bp (Fig. 1), though it still conferred tetracycline resistance. Hybridization of the gel bands to $\left[{ }^{32} \mathrm{P}\right]$.

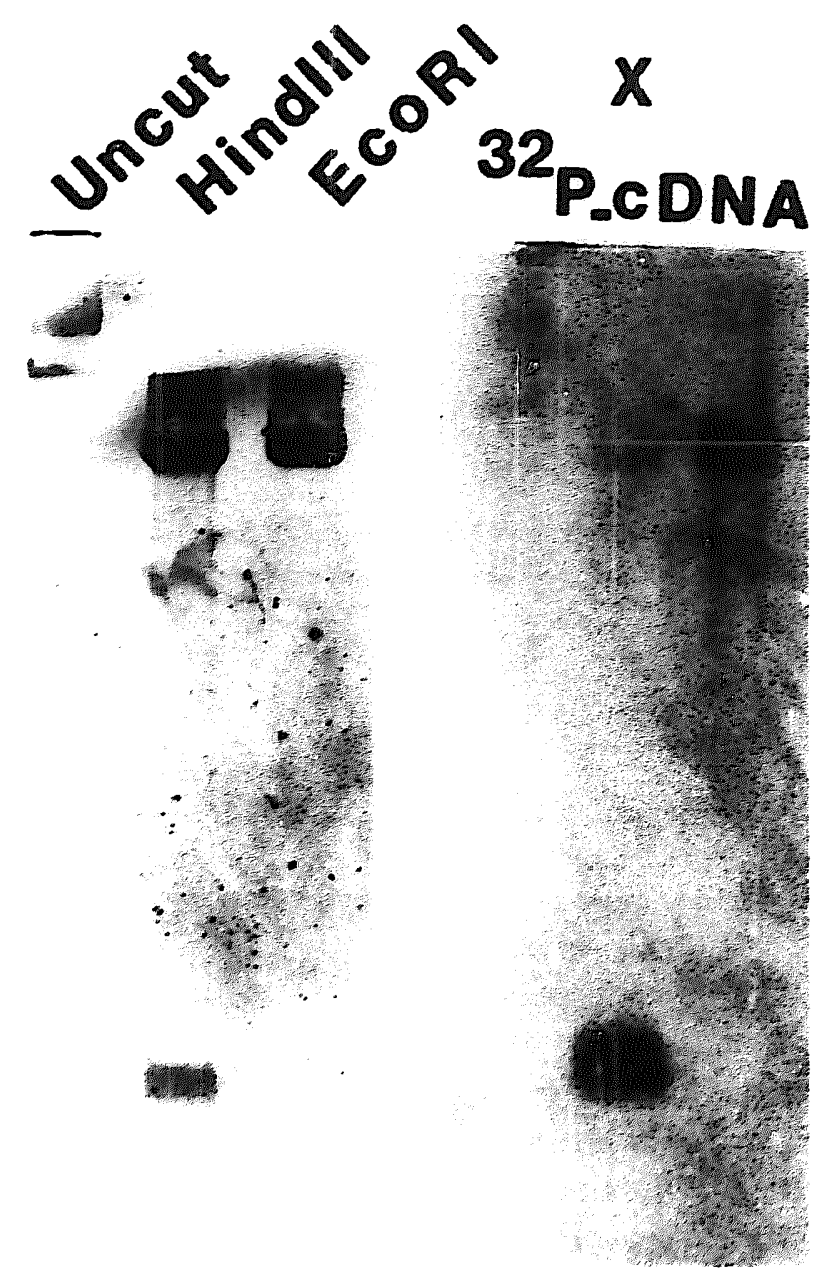

Fig. 1. Hyeridization of $\left(^{32}\right.$ P $]$ cDNAcsn with recombinant plasmid pCas51. Left panel: Hectrophoresis of pCas51 DNA either without digestion or after digestion with HindIII or licoRI. Staining is with ethidium bromide. Right panel: Autoradiography of the gel bands shown in the left panel af ier Southern blotting and hybridization to $\left[{ }^{32} \mathrm{P} ! \mathrm{cDNA}\right.$.

cDNAcsn showed that the inserted DNA segment hybridized to this probe (Fig. 1) and, therefore, contained a cloned segment of DNA corresponding to part of one of the murine casein genes.

The restriction endonuclease cleavage patterns of the complete pCas51 plasmid DNA and of the cloned fragment showed that $A l u \mathrm{I}, P s t \mathrm{I}$, and $R s a \mathrm{I}$ each cut the cloned sequence at a single site (Fig. 2). The following enzymes did not cut the cloned DNA: $A v a \mathrm{I}$, BamHI, EcoRI, Haelli, HindIII, HinfI, Mbol, SalI, TaqI.

Individual casein mRNAs were purified by electrophoresis of total oligo(dT)-bound mammary gland RNA on a $1.5 \%$ agarose preparative gel. Bands corresponding to each of the two $15 \mathrm{~S}$ casein mRNAs 


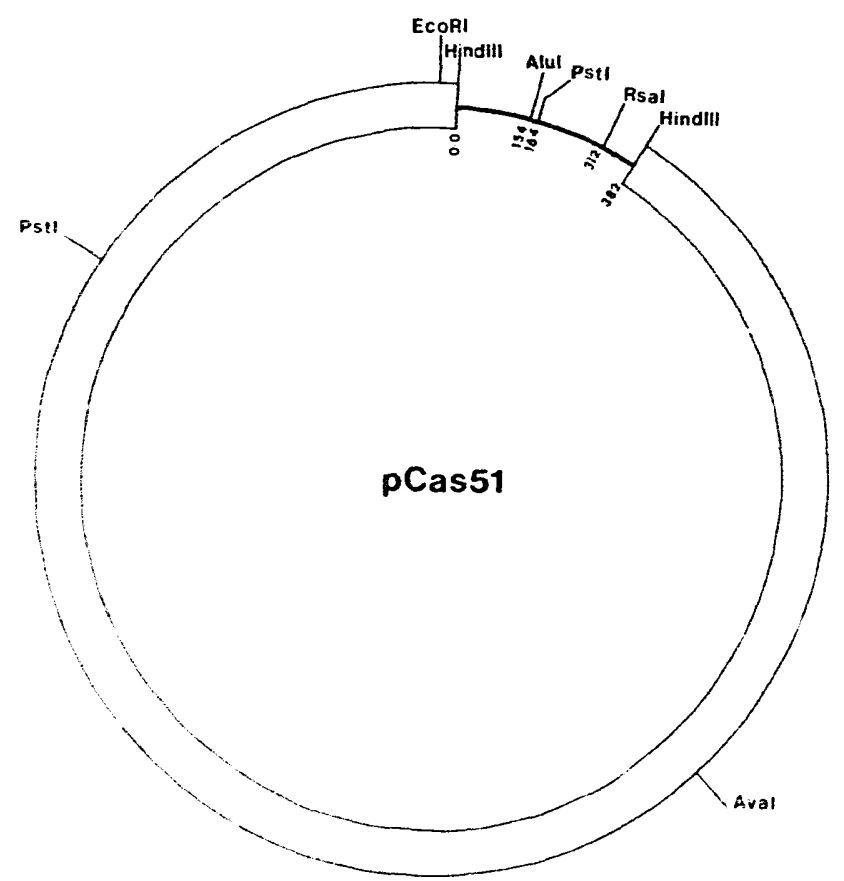

Fig. 2. Map of pCas51. The size of the plasmid (double line) is approx. $4.65 \mathrm{~kb}$. The insert DNA (single line) has single restriction sites for $A l u \mathrm{I}, P_{s t} \mathrm{I}$ and $R$ sal. The numbers indicate the size of the fragments in base pairs.

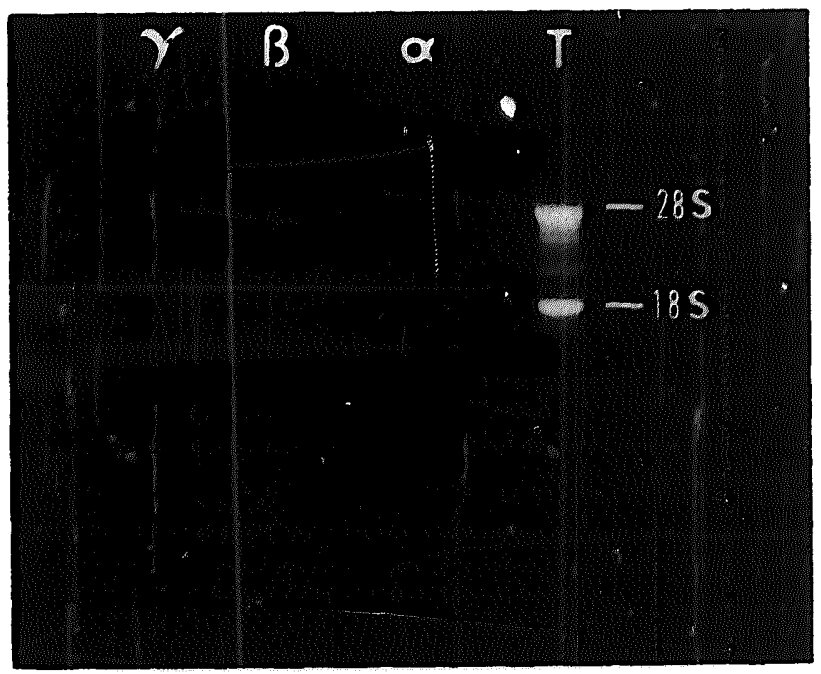

Fig. 3. Electrophoresis of purified casein mRNAs on $1.5 \%$ agarose gels. Oligo(dT)-bound RNA from 7-12 days lactating mice was first electrophoresed on a preparative agarose gel. $50 \mu \mathrm{g}$ of RNA was applied to each of twelve lanes after heat denaturation at $70^{\circ} \mathrm{C}$ for $10 \mathrm{~min}$. The bands were visualized by staining with ethidium bromide. Bands corresponding to th:e two $15 \mathrm{~S}$ casein mRNAs (mRNAcsn $a$ and $\beta$ ) a td the $12 \mathrm{~S}$ casein RNA (mRNAcsn $\gamma$ ) were excised from the gel and the RNA was eluted. Aliquots of each purified RNA were again heat denatured and re-electrophoresed on analytical agarose gels. $10 \mu \mathrm{g}$ of total RNA (T) has been electrophoresed on an adjacent lane (extreme right) to indicate the positions of the $28 \mathrm{~S}$ and $18 \mathrm{~S}$ ribosomal RNAs. An RNA band of molecular weight close to that of the mRNAcsn $\gamma$ coulu not be eliminated from the preparation.
(mRNAcsn $\alpha$ and mRNAcsn $\beta$ ) and the $12 \mathrm{~S}$ casein mRNA (mRNAcsn $\gamma$ ) vere excised separately and eluted. Fig. 3 shows that each purified RNA migrates as a discrete band in analytical agarose gel electrophöresis.

pCas51 insert was nick-translated as described by Maniatis et al. (1975), yielding the ${ }^{32} \mathrm{P}$-specific activity of $5 \times 10^{7}$ to $1 \times 10^{\varepsilon} \mathrm{cpm} / \mu \mathrm{g}$. Solution hybridizations of such ${ }^{32}$ P-labelec DNA to purified mRNAcsn $\alpha, \beta$, and $\gamma$ were done using modifications of the procedure described by Bishop (1972). Table I shows that the cloned sequence is complementary primarily to mRNAcsn $\beta$. This result was confirmed by hybridization of each RNA with the insert DNA and subsequent translation in a rabbit reticulocyte lysate cellfree system followed by immunoprecipitation with mouse casein antibody. Only the synthesis of casein from mRNAcsn $\beta$ was completely inhibited by the hybridization (data not shown).

\section{TABLE I}

Hybridization of purified casein mRNAs to $\left[^{32} \mathrm{P}\right]$ pCas 51 insert DNA

\begin{tabular}{llll}
\hline Sample & $\begin{array}{l}\text { Time of } \\
\text { hybridi- } \\
\text { zation } \\
\text { (h) }\end{array}$ & $\begin{array}{l}\text { DNA } \\
\text { hybridized a } \\
\text { (cpm) }\end{array}$ & $\begin{array}{l}\text { Hybridi- } \\
\text { zation b }\end{array}$ \\
\hline mRNAcsn $\alpha$ & 12 & 296 & 2.43 \\
& 24 & 343 & 1.68 \\
mRNAcsn $\beta$ & 12 & 1490 & 83.10 \\
mRNAcsn $\gamma$ & 24 & 1594 & 86.21 \\
& 12 & 272 & 0.81 \\
Wheat germ tRNA & 12 & 335 & 1.14 \\
& 24 & 237 & 0 \\
pCas51 insert DNA & 12 & 316 & 0 \\
(reannealing) & 24 & 318 & - \\
\hline
\end{tabular}

a $3000 \mathrm{cpm}$ of double-stranded pCas51 insert DNA was used per reaction. The DNA was denatured by heating at $100^{\circ} \mathrm{C}$ for $5 \mathrm{~min}$ and quick chilling. immediately before adding to the reaction mixture. Hybridized cpm were determined by $\mathrm{S} 1$ nuclease digestion and subsequent TCA precipitation.

b Percent hybridization values were obtained after correcting for the reannealing of the double-stranced DNA and for the fact that only one strand hybridizes to its complementary RNA. 


\section{ACKNOWLEDGEMENTS}

We would like to thank Arvilla Kirchhoff for excellent secretarial assistance and Michael Leiser for help in mapping restriction sites. This work was supported by N.I.H. grants CA11058 and CA25304 to M.R.B. and GM25565 to R.B.H. We thank Dr. J.W. Beard of Life Sciences, Inc. for the gift of AMV reverse transcriptase.

\section{REFERENCES}

Adams, J., Kinney, T., Thompson, S., Rubin, L. and Helling, R.B.: Frequency-depend-nt selection for plasmid-containing cells of Escherichia coli. Genetics 91 (1979) 627637.

Banerjee, M.R.: Responses of mammary cells to hormones. Int. Rev. Cytol. 46 (1976) 1-97.

Bishop, J.0.: Molecular hybridization of ribonucleic acid with a large excess of deoxyribonucleic acid. Biochem. J. 126 (1972) 171-185.

El-Gewely, M.R. and Helling, R.B.: Preparative separation of DNA-ethicium bromide complexes by zonal density gradient centrifugatior. Anal. Biochem, 102 (1980) 423428.

Ganguly, R., Ganguly, N., Mehta, N.M. and Banerjee, M.R.: Absolute requirement of glucocorticoid for $P$ vpression of the casein gene in presence of prolactin. Proc. Natl. Acad. Sci. USA 77 (1980) 6003-6006.

Ganguly, R., Mehta, N.M., Ganguly, N. and Banerjee, M.R.: Glucocorticoid modulaticn of casein gene transcription of mouse mammary gland. Proc. Natl. Acad. Sci. USA 76 (1979) 6466-6470.

Maniatis, T., Jeffrey, A. and X̄leid, D.B.: Nucleotide sequence of the rightward operator of phage $\lambda$. Proc. Natl. Acad. Sci. USA 72 (1975) 1184-1 188.

McKnight, G.S. and Palmiter, R.D.: Transcriptional regulation of the ovalbumin and conalbumin genes by steroid hormones in the chick oviduct. J. Biol. Chem. 254 (1979) 9050-9058.

Mchta, N.M., Ganguly, N., Ganguly, R. and Banerjee, M.R.: Hormonal modulation of the casein gene expression in a mammogenesis-lactogenesis two-step culture model of whole mammary gland of the mouse. J. Biol. Chem. 255 (1980) 4430-4434.

Peacock, A.C. and Dingman, C.W.: Resolution of multiple ribonucleic acid species by polyacrylamide gel electrophoresis. Biochemistry 5 (1967) 1 818-1 827.

Rodriguez, R.L., West, R.W., Heyneker, H.L., Bolivar, F. and Boyer, H.W.: Characterizing wild-type and mutant promoters of the tetracycline resistance gene in pBR313. Nucl. Axids Res. 6 (1979) 3267-3287.

Southern, E.M.: Detection of specific sequences among DNA fragments separated by gel electrophoresis. J. Mol. Biol. 98 (1975) 503-517.

Thomas, P.: Hybridization of denatured RNA and small DNA fragments transferred to nitrocellulose. Proc. Natl. Acad. Sci. USA 77 (1980) 5 201-5 205.

Widera, G., Gauthier, F., Lindenmaier, W. and Collins, J.: The expression of tetracycline resistance after insertion of foreign DNA fragments between the EcoRI and HindIII sites of the plasmid cloning vector pBR322. Mol. Gen. Genet. 163 (1978) 301-305.

Communicated by $\mathbf{Z}$. Hradečná. 